"An assessment of the challenges of adopting and implementing IFRSS for SMEs in South Africa"

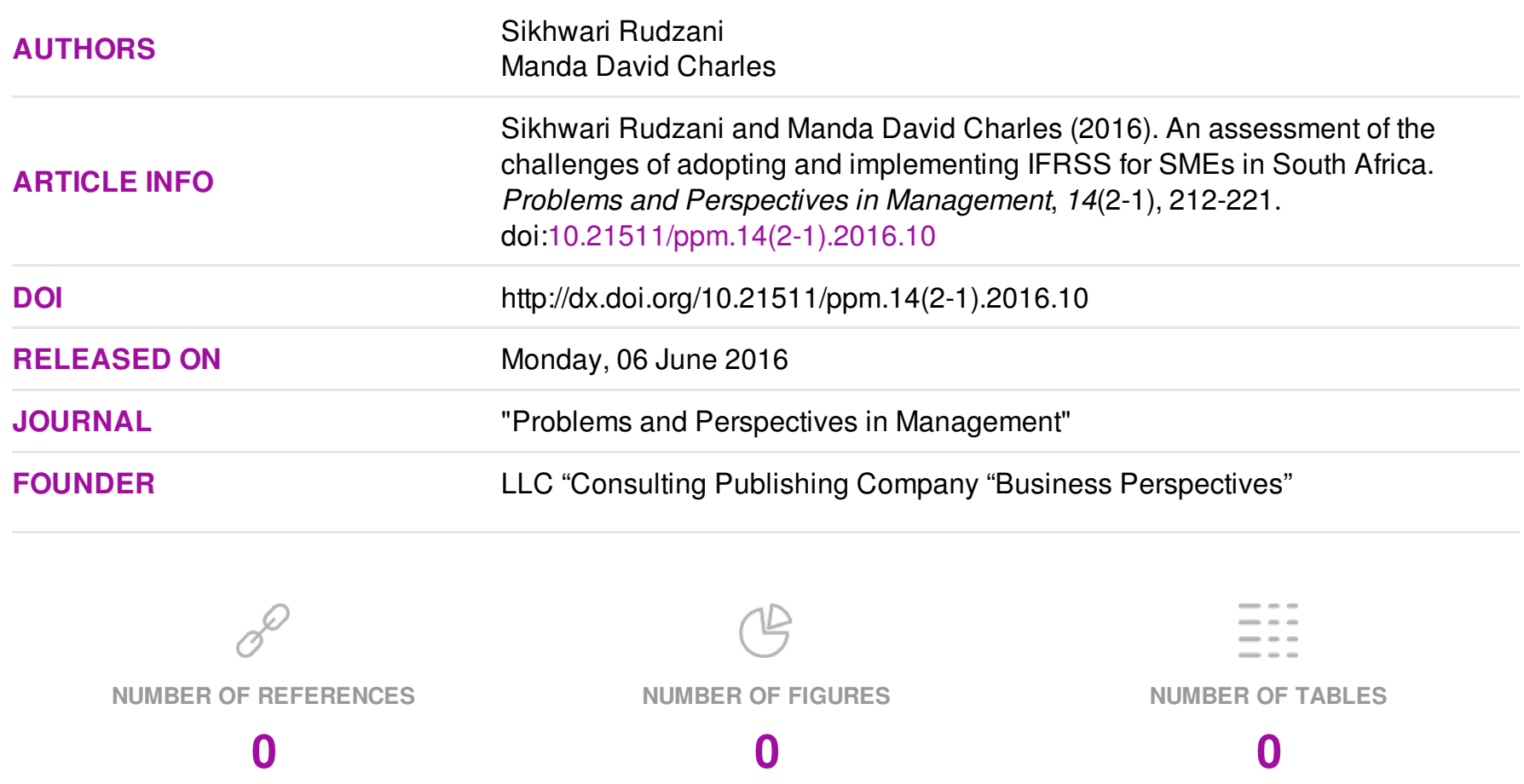

(C) The author(s) 2022. This publication is an open access article. 
Sikhwari Rudzani (South Africa), David Charles Manda (South Africa)

\title{
An assessment of the challenges of adopting and implementing IFRS for SMEs in South Africa
}

\begin{abstract}
The purpose of this study is to assess the challenges faced by small and medium sized enterprises (SMEs) in adopting and implementing International Financial Reporting Standards (IFRS) for SMEs in South Africa. There is a perception that, although SMEs are required to use IFRS for SMEs in South Africa, many of these entities are finding it difficult to adopt or implement the IFRS for various reasons including lack of the necessary expertise. The objective of the study is to establish, empirically, the reasons and, subsequently, to determine the attributing causes of the problem, if that was the case.
\end{abstract}

The study is based on a sample of randomly selected number of SMEs in Vhembe district, Thohoyandou, Limpopo province, South Africa. The study findings show that many SMEs in Vhembe District (67\%) have adopted IFRS for SMEs in various forms and degree, but, generally, SMEs still find challenges in implementation due to lack of resources. For compliance purposes, however, even those SMEs which have not substantially implemented the IFRS for SMEs are expected to prepare their financial statements by referring to the guidelines.

Consequently, this raises a problem when comparing financial performance of various SMEs whose financial statements are prepared using different approaches. The study findings serve as a reminder to the accounting profession about the challenges that SMEs face when they attempt to adopt IFRS for SMEs.

Keywords: IFRS, SMEs, challenges, adoption, implementation, expertise.

JEL Classification: M41.

\section{Introduction}

The International Accounting Standards Board (IASB) issued the International Financial Reporting Standards for small and medium entities (IFRS for SMEs, 2007) whose objective was to provide a simplified, selfcontained set of accounting principles that are appropriate for small and non-listed companies. IFRS for SMEs are based on full IFRS which are developed primarily for listed companies.

Despite the fact that the IFRS for SMEs are less demanding than the full IFRS, there is a perception that most SMEs, especially in developing countries like South Africa, may not have the resources to adopt or adequately implement those standards. Consequently, departure from using the uniform framework of accounting would, among others, make it difficult to compare performance of the SMEs. It is against this background that there is a need for empirical evidence to test the validity of this assumption.

The aim of the study, therefore, was to determine the challenges, if any, that SMEs face in adopting and implementing the IFRS for SMEs, especially in South Africa.

\section{Definitions}

The importance of the SME sector and the informal sector is acknowledged internationally, but defining an SME is a challenging task, as every country has

(c) Sikhwari Rudzani, David Charles Manda, 2016.

Sikhwari Rudzani, University of Venda, South Africa.

David Charles Manda, MBA, CPA (Australia), Senior Lecturer (Accounting and Auditing), University of Venda, South Africa. its own definition. There is no single, uniformly accepted definition of a 'small firm' (Storey, 1994). Firms differ in their levels of capitalization, sales and employment, hence, definitions which employ measures of size for example, number of employees, turnover, profitability and net worth, when applied to one sector might lead to all firms being classified as small, while the same definition when applied to a different sector might lead to a different result.

SME definitions can be broadly categorized into two, 'economic' and 'statistical' definitions. Under the economic definition, a firm is regarded as small if it meets the following three criteria: (1) it has a relatively small share of their market place; (2) it is managed by owners, or part owners, in a personalized way and not through the medium of a formalized management structure and (3) it is independent in that it is not part of a larger enterprise (Mahembe, 2011). The 'statistical' definition, on the other hand, is used in three main areas: (1) quantifying the size of the small firm sector and its contribution to GDP, employment and exports; (2) comparing the extent to which the small firm sector's economic contribution has changed over time and (3) in a cross-country comparison of the small firms' economic contribution. These definitions, however, have a number of weaknesses. For example, the economic definition, which states that a small business be managed by its owners or part owners in a personalized way and not through the medium of a formal management structure, is incompatible with its statistical definition of, for example, a small manufacturing firm which might have up to 200 employees (Mahembe, 2011). 
However, the approach of considering level of turnover figures has been applied in other jurisdictions to determine what constitutes a small and medium enterprise. A survey of 12 countries which employ a definition of a small and medium enterprise (SME) including Australia, Austria, Canada, Finland, France, Germany, Ireland, Netherlands, New Zealand, Spain and Switzerland shows that turnover figures are a critical factor in the definitions employed, although there are marked differences in the thresholds.

1.1. In South Africa. At national level, according to the Davis Tax Committee (2014), there is currently no single accepted definition of small and medium size business in South Africa. For instance, the Committee cites the National Development Plan (NDP): Vision for 2030 (November, 2011), the National Small Enterprise Act, 1996 (Act No. 102 of 1996) as amended and the Income Tax, 1962 (Act No. 58 of 1962) as amended and notes that each has its own interpretation and definition. The NDP identifies three categories of business within the SME sector as survivalist, lifestyle and entrepreneur. The NDP regards a survivalist business as essentially a home-based business or one which operates on the streets.

The National Small Enterprise Act, 1996 defines a small enterprise as a separate and distinct business entity, together with its branches or subsidiaries, if any, including co-operative enterprises, managed by one owner or more predominantly carried on in any sector or subsector of the economy and classified as either micro, very small, a small or medium enterprise. Except in the case of agriculture, a medium-size business has been defined as a business which has a total full-time paid employee complement of 200 or more. A small business has 50 employees, a very small business 20 employees and micro business 5 employees. The total turnover for a medium-size business ranges from a minimum of R5 million in the case of wholesale, trade with commercial agents and allied services. Small businesses range from R 3 million to R32 million, very small from R500 000 to R6 million, and micro businesses, generally, are defined with a turnover of up to R200 000. Turnover seems to be the most preferred indicator to use, both internationally and locally.

The gross asset value (excluding fixed property) fluctuates from R5 million to R23 million for medium-size businesses, from R1 million to R6 million for small businesses, and from R500 000 to R2 million for very small businesses. Micro businesses have a gross asset value of R100 000 .
For the purposes of income tax, two definitions are relevant. The first is that, for a micro business, as set out in Part 2 of the Sixth Schedule to the South African Income Tax Act, 1962 in terms of which a person qualifies as a micro business if that person is:

- a natural person (or the deceased or insolvent estate of a natural person that was a registered micro business at the time of death or insolvency); or

- a company where the qualifying turnover of that person for the year of assessment does not exceed an amount of R1 million.

The second definition in the Income Tax Act, section 12E (4) defines a small business corporation as any close corporation or co-operative or any private company, all shareholders of which are, at all times during the year of assessment, natural persons and where the gross income for the year of assessment does not exceed R20 million per annum (with effect from 2014 year of assessment). Other qualifying requirements are also applicable.

\section{Research questions}

For the purpose of this study, the following research questions will be considered:

- To what extent have South African SMEs adopted IFRS for SMEs?

- What challenges have stopped them from doing so, if they have not adopted the standards?

- What implementation challenges they face, if any, if they chose to adopt the standards?

\section{Literature review}

There is consensus among policy makers, economists and business experts that SMEs are drivers of economic growth (Mahembe, 2011). A healthy SME sector contributes prominently to the economy through creating employment opportunities, generating higher production volumes, increasing exports and introducing innovation and entrepreneurship skills. Mahembe (2011) further notes that SMEs are the first step towards industrialization and their dynamic role in developing countries positions them as engines through which these countries' growth objectives can be achieved. Similarly, since SMEs have a huge impact on the South African economy, it is critical that they are given all the necessary incentives to become successful in order to grow the economy.

It is anticipated that most companies that do not have 'public accountability' and which publish generalpurpose financial statements for external users may adopt the IFRS for SMEs. The standard is available to other entities looking to prepare a set of accounts that 
can be described as 'fairly presenting' under an accounting framework. This includes companies, close corporations, partnerships, sole traders and trusts where the trust deeds permit (IASB, 2007a).

IFRS for SMEs has simplifications which reflect the needs of users of SMEs' financial statements. Although prepared on general IFRS foundations, IFRS for SMEs is a stand-alone framework, which is separate from the general IFRS. These standards have replaced the statement of Generally Accepted Accounting Practices (GAAP) for SMEs issued by the South African Accounting Practices Board (APB) in 2007 to provide relief to 'limited interest' entities. In South Africa, this came into effect from 1 December 2012. From this period, all entities that were to transition from the South African Generally Accepted Accounting Practices (SA GAAP) to International Financial Reporting Standards (IFRS) were required to comply with IFRS 1 - First-time Adoption of International Financial Reporting Standards, and those that changed over to the International Financial Reporting Standard for Small and Medium-sized Entities (IFRS for SMEs) are required to comply with Section 35 of the IFRS for SMEs - Transition to the IFRS for SMEs. The International Accounting Standards Board (IASB) has provided several exceptions to entities to ease the transition to either IFRS or IFRS for SMEs, but retrospective application remains the general rule under both frameworks. Entities are, therefore, requested to carefully consider the impact of the transitional requirements in IFRS 1 and Section 35 on their financial statements (APB, March 2012).

The Companies Act Regulations, 2011 in South Africa, prescribe the reporting frameworks based on each individual company's public interest score. Although the Regulations permit the use of either IFRS, IFRS for SMEs or SA GAAP in specific instances, the decision made by the APB and the Financial Reporting Standard Council (FRSC) in 2012 to withdraw SA GAAP has effectively meant that IFRS and IFRS for SMEs will be the only recognized frameworks. The FRSC was formed in 2011 as the legally constituted standard setter in South Africa which would replace the APB.

According to IASB (2007c, p. 3), IFRS for SMEs would provide the following benefits:

- improve the comparability of financial information of SMEs at either national or international level;

- make it easier to implement planned cross-border acquisitions and to initiate proposed partnerships or cooperation agreements with foreign entities;

- help SMEs to reach international markets, and
- enhance the financial health of the SMEs.

Despite the benefits cited above, IFRS for SMEs still have considerable threats, including the possibility of cost of its adoption exceeding the anticipated benefits. Consequently, mixed reactions have continued to be voiced during the debates on the abolition of local reporting standards for international reporting standards (Kennedy and Emmanuel, 2013). Poroy \& Sipahi (2007) note that the transition to IFRS for SMEs will be difficult because of the low corporate level of SMEs and the differences between tax legislation and IFRS for SMEs. In terms of benefit from access to financial markets, Riva and Salotti (2015) observe that SMEs tend to use inner resources rather than raise funds from banks. Further, their study dismisses the statistical significance of relationships related to accounting disclosure with the cost of credit.

The question of whether the proposed IFRS for SMEs will be suitable for the smaller entities within the SME arena has been raised by Roberts and Sian (2006) in their paper entitled "Micro-entity Financial Reporting: Perspectives of Preparers and Users". Roberts and Sian (2006) are concerned that the low level of literacy, lack of accounting education, and absence of computerized accounting systems may impair the ability of such entities to produce financial information, in accordance with IFRS, in less developed economies. In South Africa, for example, there are only few provinces and cities that are developed and have enough resources that can be used to comply with the standards. Lekhanya (2013) notes that "people working in rural SMEs in KZN (Kwazulu-Natal), including business owners/managers do not have accounting and financial management skills". Further, Lekhanya (2013) cites Danie and Pieter (2011) who observe that the introduction of international Financial Reporting Standards has made it more difficult for SMEs to adhere to accounting requirements.

Some of the challenges resulting from adoption of IFRS for SMEs have been reported in previous studies conducted by other researchers. Alp and Ustundag (2009) cite potential knowledge shortfall as a challenge that SMEs in developing countries face when adopting and implementing IFRS for SMEs. Alp and Ustundag (2009) observe that the transition plan to IFRS and its implications for preparers and users of financial statements, regulators, educators and other stakeholders, have to be effectively coordinated and communicated. They argue that this should include raising awareness on the potential impact of the conversion, identifying regulatory synergies to be derived and communicating the temporary impact of the 
transition on business performance and financial position. Further, they are mindful that the implementation of IFRS requires considerable preparation both at the country and entity levels to ensure coherence and clarity on the authority that IFRS will have in relation to other existing national laws (Alp and Ustundag, 2009).

Irvine and Lucas (2006) cite lack of accounting education and training as one of the challenges SMEs face in adopting the standard. They note that practical implementation of IFRS requires adequate technical capacity among preparers and users of financial statements, auditors and regulatory authorities. More importantly, they emphasize that training materials on IFRS are often not readily available at affordable costs. Critics argue that the transition process from local GAAP/full IFRS to the IFRS for SMEs may impose certain difficulties on business practices, processes and systems, which often turn out to be too costly, complex and prolonged for small entities to handle. Irvine and Lucas (2006) further observe that countries that implemented IFRS faced a variety of capacityrelated issues, depending on the approach they took. They recognize that, usually, the time lag between decision date to adopt the standards and the actual implementation date may not be sufficiently long enough to recruit, or train a good number of professionals who could competently apply these standards. Similarly, South Africa, like many other developing countries, is encountering an acute shortage of accountants and auditors who are technically competent in implementing IFRS, especially at the level of SMEs.

The Australian Accounting Standards Board (AASB) is of the view that the IFRS for SMEs still appear to be complex in the recognition and measurement requirements (AASB, 2009). For these reasons, Australia has so far not adopted the IFRS for SMEs. Instead, the AASB has adopted the Reduced Disclosure Regime (RDR) implemented under the revised differential reporting framework for issuing new accounting standards, AASB (2010). Alp and Ustundag (2009) and the United Nations Conference on Trade and Development (UNCTAD, 2007a) point out that the successful enforcement of international standards at each country level will be challenging in the absence of consistency in the regulatory framework and the legal backing of IFRS. Within this context, the implementation of the IFRS for SMEs in many countries is confronted with national legislation requirements. In many cases, SMEs are required to prepare financial statements in compliance with certain tax legislation, especially for the purpose of filing tax returns. Countries such as Lebanon,
Slovakia, Austria, and Russia believe that SMEs favor preparing financial statements for tax purposes only (IFRS Foundation, 2011). Balsari and Varan (2014) note that Turkish accounting system has been rule-based aimed at reporting for tax authorities, and, in addition, the business culture in the country does not support transparency. Similarly, in this study, many SMEs interviewed in South Africa prepare financial statements in compliance with tax legislation, and tender processes, rather than in compliance with IFRS for SMEs.

In Germany, financial statements usually serve a multi-purpose function and, therefore, SMEs prefer to prepare a single set of financial statements which also satisfy taxation purposes (Evans et al., 2005). Evans, Armstrong, Barth et al. (2008) note that investors in European firms would react negatively to the adoption of IFRS for SMEs because of the regional differences in the economies, perception of investors that these standards might lower the quality of reports locally, and the fear of the investors that the implementation and transition costs associated with IFRS would be much higher than the benefits to be acquired. Further, Samujh and Devi (2015) conclude that the IFRS for SMEs are not appropriate for ASEAN countries. They argue that instead of aiding SMEs economic growth, IFRS for SMEs may create a burden to growth through unnecessary imposition of financial reporting and regulatory requirements which inadvertently may result in reduced entrepreneurship activity. Based on these findings from different countries, one can argue that despite the suggested benefits, the IFRS for SMEs are perceived to be a burden and too difficult for some SMEs to adopt.

\section{Research methodology}

In this study, both desk search and questionnaire interviews were used to collect information.

Structured and unstructured questionnaires based on the research questions developed were administered on a randomly selected SMEs in and around Thohoyandou in Vhembe District, Limpopo Province, South Africa. The questionnaire was used to collect primary data, because it allowed respondents enough space to complete the questionnaire at their own time. To ensure compliance with ethical requirements, the participation of the SMEs and other individuals involved was entirely voluntary and confidential. Data collection involved respondents from a sample of 30 SMEs and four accounting firms in Thohoyandou. The consultancy firms were included, because they are, from time to time, involved in auditing books, including those of 
SMEs. Similarly, interviewees included finance managers and accountants of the SMEs, among others. The statistical software 'SAS/STATA' was used to analyze the descriptive qualitative data that were, finally, presented as tables and graphs to present the generated responses.

\section{Results and discussion}

Table 1. Level of preparation of financial statements

\begin{tabular}{|c|c|c|c|c|c|c|c|c|}
\hline Preparation of financial statements & Yes & No & $\begin{array}{c}\text { Companies accountant/s } \\
\text { (employee) }\end{array}$ & $\%$ & Consultancy firm & $\%$ & $\begin{array}{l}\text { Total number of } \\
\text { respondents }\end{array}$ & Total \% \\
\hline $\begin{array}{l}\text { Do you prepare financial } \\
\text { statements? }\end{array}$ & 29 & 1 & & $97 \%$ & & $3 \%$ & 30 & $100 \%$ \\
\hline $\begin{array}{l}\text { Who prepares financial statements } \\
\text { for the company? }\end{array}$ & & & 4 & $14 \%$ & 25 & $86 \%$ & 29 & $100 \%$ \\
\hline
\end{tabular}

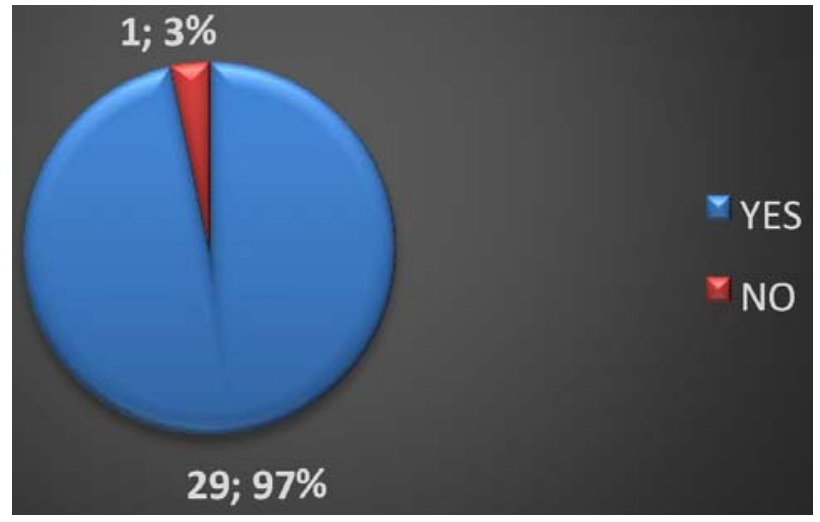

Fig. 1. Do you prepare financial statements?

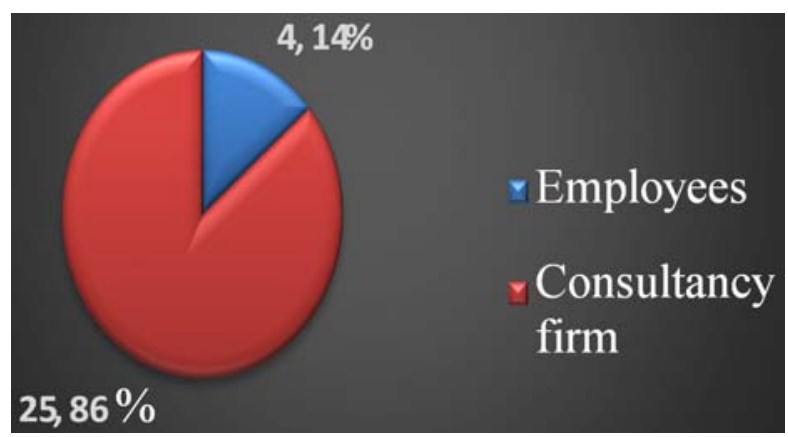

Fig. 2. Who prepares the financial statements?

Table 1 shows that most or nearly all of the to prepare the statements. Further, only $14 \%$ have respondents do prepare financial statements. their own company employees to prepare the For those who prepare the financial statements, and they are all accounting statements, $86 \%$ hire accounting and audit firms and audit firms.

Table 2. Level of adoption of IFRS for SMEs

\begin{tabular}{|c|c|c|c|c|c|c|c|c|}
\hline Level of adoption & Fully adopted to IFRS for SMEs & $\%$ & Partially adopted to IFRS for SMEs & $\%$ & Not adopted & $\%$ & Total & Percentage \\
\hline Mainstream SMEs & 20 & $67 \%$ & 2 & $6 \%$ & 8 & $27 \%$ & 30 & $100 \%$ \\
\hline
\end{tabular}

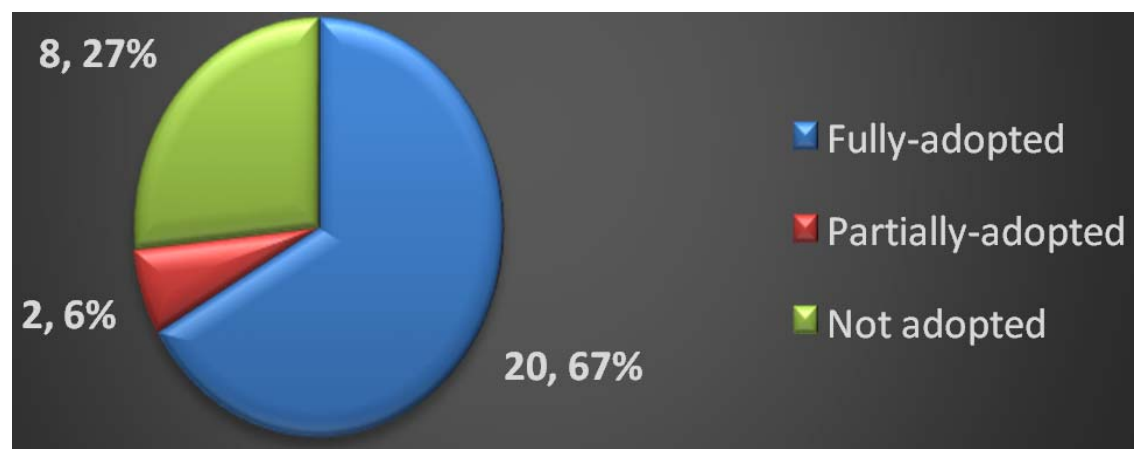

Fig. 3. Level of adoption of IFRS for SMEs 
Given that not many companies worldwide have fully adopted the use of IFRS for SMEs, South Africa has done exceptionally well at $67 \%$. The IFRS for SMEs was adopted in South Africa in 2007, when it was in its Exposure Draft, and most of the companies have used the new framework long before it was formally adopted nationally in 2012 . The results of the survey indicate positive response to the standard by SMEs in Vhembe. Out of 30 companies under Mainstream SMEs, 20 reported to have fully adopted the standard, and only 8 SMEs $(27 \%)$ are still using the SA GAAP. The high level of adoption by SMEs in Vhembe contradicts the perception that most SMEs would not be able to adopt the IFRS for SMEs due to lack of technical expertise or inability to hire the relevant expertise. Furthermore, consultancy firms were part of the Mainstream SMEs and contributed to the high percentage of full adoption. Partially-adopted in this study basically mean both SA GAAP and IFRS for SMEs are being used, therefore, only 2 SMEs have partially-adopted the new standard (IFRS for SMEs). One of the main issues raised during the study is how to measure the level of IFRS for SMEs adoption. For example, researchers argue that it is important to spell out if adoption of IFRS for SMEs is a law, and, if so, what are the accompanying penalties for non-compliance. Further, while many developing countries claim to have adopted IFRS for SMEs fully, there are ambiguities in the interpretation of what constitutes IFRS for SMEs adoption. Despite the claim that a country has fully adopted IFRS for SMEs as published by IASB, various organizations have applied the standards in some modified form to comply. One of the most effective way to check if, indeed, a country has fully adopted IFRS for SMEs is to verify if the companies' financial statements comply with the requirement of the accounting standards.

Another interesting observation is that, although many developing countries have seemingly fully adopted the IASB IFRS for SMEs, many, if not all developed countries, including the USA, European Union, Russia, China and Japan have yet to do so. This has created a feeling that developing countries are forced by international financial institutions like the World Bank, IMF and the others to adopt and comply with requirements they may not be ready to implement in order to be rated creditworthy. Naturally, if this trend does not change, it will continue to compromize the whole objective of harmonization and compatibility of the financial statements internationally.

Table 3. Challenges of implementing IFRS for SMEs

\begin{tabular}{|c|c|c|c|c|c|c|}
\hline Respondents & Yes (MSS\&CF) & $\%$ & No (MSS\&CF) & $\%$ & Total number of & Total \% \\
\hline Lack of skills to implement it & 15 & $68 \%$ & 7 & $32 \%$ & 22 & $100 \%$ \\
\hline Too costly to implement & 13 & $59 \%$ & 9 & $41 \%$ & 22 & $100 \%$ \\
\hline Users of our financial statements complain that they are now complicated & 7 & $32 \%$ & 15 & $68 \%$ & 22 & $100 \%$ \\
\hline Require more staff & 4 & $18 \%$ & 18 & $82 \%$ & 22 & $100 \%$ \\
\hline We adopted it against our will & 9 & $41 \%$ & 13 & $59 \%$ & 22 & $100 \%$ \\
\hline Has added no value to the business & 4 & $18 \%$ & 18 & $82 \%$ & 22 & $100 \%$ \\
\hline
\end{tabular}

Table 3 shows that, in general, the 22 respondents who have adopted and are implementing the IFRS for SMEs, face the following challenges: lack of skills to implement it (68\%), high cost of implementation (59\%), adopted it against their will $(41 \%)$, users of the financial statements complain that they are now too complicated (32\%), require more staff $(18 \%)$ and have added no value to the business $(18 \%)$. The finding that $82 \%$ of users of IFRS for SMEs in South Africa agree that it has added value to their business is crucial, as it contradicts the general assumption and observations drawn from the literature review. The added benefits referred to, will among others, include qualification to government tenders and bank loans. Based on this assumption, one would expect these SMEs to attract more business or sales and to find it easier to obtain bank loans, however, findings below (Table 4) do not support this assumption. On the other hand, the $68 \%$ of the respondents who are challenged by the lack of knowledge of IFRS for SMEs, and lack of their own staff that are competent to use IFRS for SMEs, support the common assumption that there is a shortage of well-qualified accountants and other financial management expertise. In addition, some respondents $(59 \%)$ cited the high cost of using IFRS for SMEs or outsourcing of the required expertise, where they cannot recruit their own staff, as a second major challenge. In some cases, business owners are not willing to change from the old system of SA GAAP. The $41 \%$ of the respondents who confirmed to having adopted the IFRS for SMEs against their will, are of interest. The information tends to support the view that some SMEs adopted the IFRS for SMEs for taxation and government tender application compliance. To minimize the challenges of, and to sensitize the SMEs on adopting IFRS for SMEs in South Africa, the Institute of Chartered Accountants in South Africa ( SAICA) launched an electronic guide for applying the IFRS for SMEs particularly for micro-entities. 


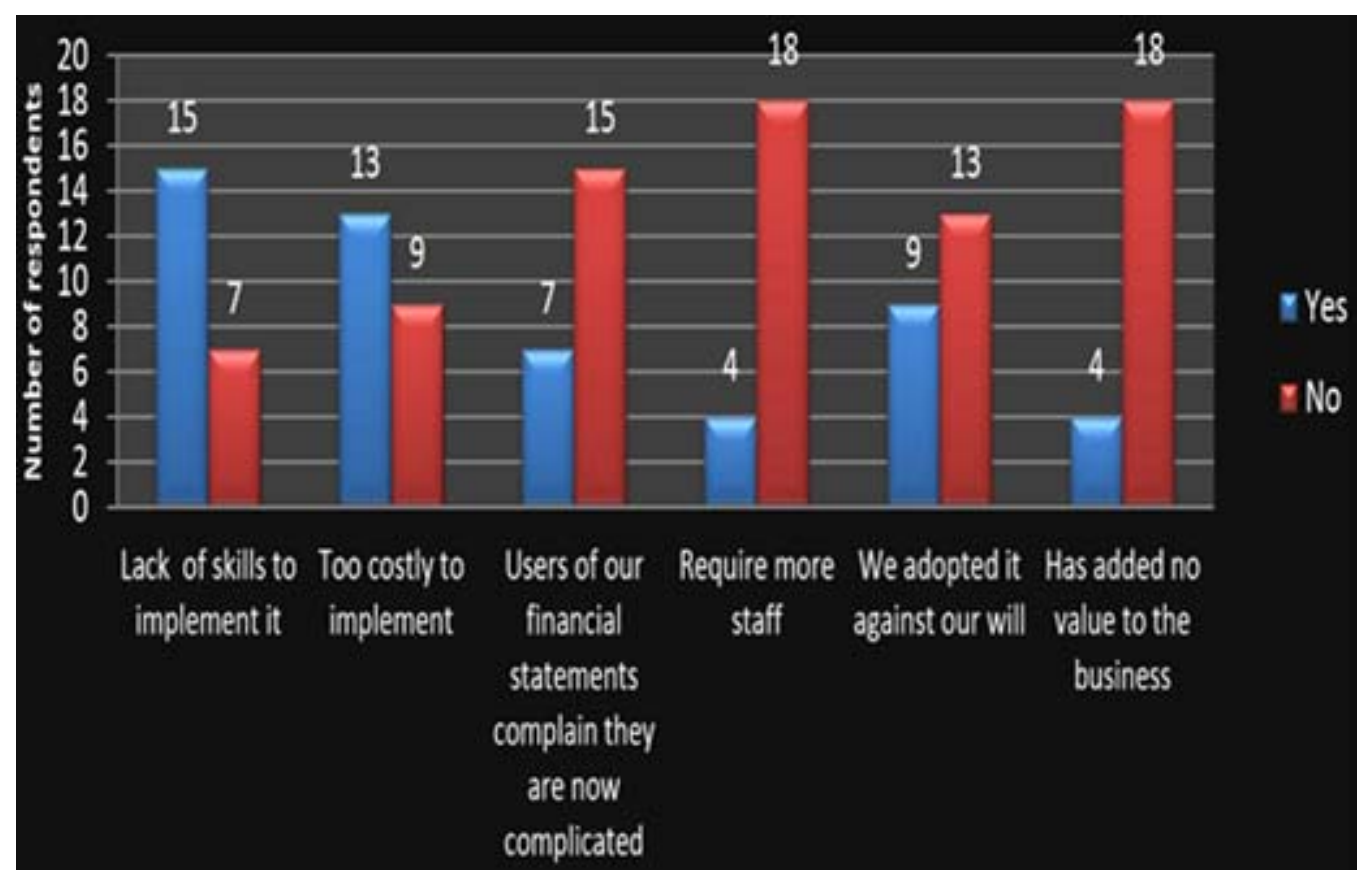

Fig. 4. Challenges of implementing IFRS for SMEs

Table 4. Benefits of using IFRS for SMEs

\begin{tabular}{|l|c|c|c|c|c|c|}
\hline \multicolumn{1}{|c|}{ Respondents } & Yes (MSS\&CF) & $\%$ & No (MSS\&CF) & $\%$ & Total number of respondents & Total \% \\
\hline Attracted more business/sales & 5 & $23 \%$ & 17 & $77 \%$ & 22 & $100 \%$ \\
\hline Easier to get bank loans than before & 9 & $41 \%$ & 13 & $59 \%$ & 22 & $100 \%$ \\
\hline Users of our financial statements like it & 8 & $36 \%$ & 14 & $64 \%$ & 22 & $100 \%$ \\
\hline Our management likes it & 11 & $50 \%$ & 11 & $50 \%$ & 22 & $100 \%$ \\
\hline None & 2 & $9 \%$ & 20 & $91 \%$ & 22 & $100 \%$ \\
\hline
\end{tabular}

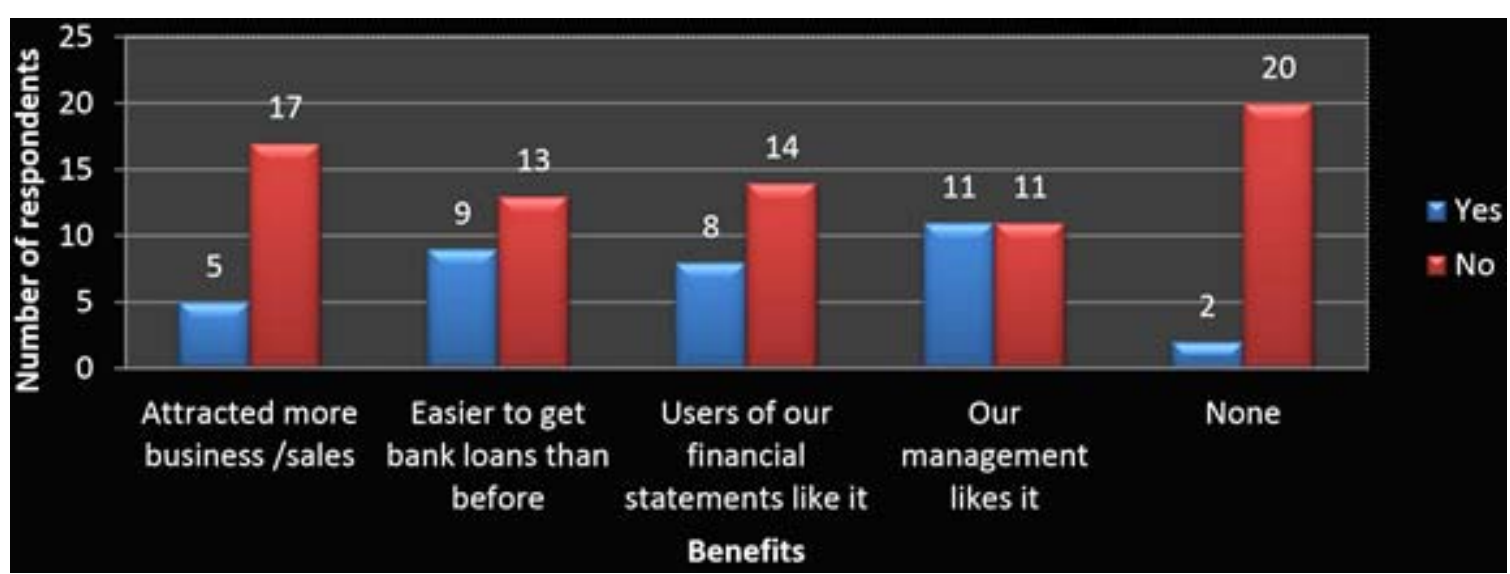

Fig. 5. Benefits of using IFRS for SMEs

Table 4 shows that $41 \%(9: 22)$ of the respondents felt that the most dominant benefit they get is the easy access to bank loans, in addition to liking the way financial statements are now presented when using IFRS for SMEs. Nonetheless, 59\% did not see much benefit in the use of IFRs for SMEs.

It must be noted that most of the SMEs in Vhembe District would be at the level of micro-enterprise and are likely to use basic accounting concepts and, generally, they cannot afford to employ professional accountants in their business. To this extent, one might argue that they may not be representative of
SMEs in South Africa, although these were the target entities for the SAICA electronic toolkit guide.

Only $23 \%$ of the respondents agreed that preparing financial statements using IFRS for SMEs attracted more business or increased turnover, whereas $77 \%$ does not agree. This may sound contradictory, considering that $67 \%$ of the respondents agreed to have adopted the IFRS for SMEs, hoping that this would boost their businesses. It can be deduced that some respondents, 67\%, might have suspected that the study was conducted on behalf of the government to track SMEs which have not complied 
with the Companies Act, 2011 regulations and this may have influenced their responses. Further, it must be recognized that one of the main objectives of the framework is to open the international market for SMEs, so that they can easily access capital funds from the international market when the need arises. The IASB (2009) argues that, if capital providers do not understand or have confidence in the financial information they receive, an SME's access to, and cost of capital will suffer. Consequently, the issue of IFRS for SMEs in 2009 was a direct response to address those concerns. However, this is not the case among SMEs in Vhembe District, South Africa, as most of the SMEs would not have the capacity to borrow funds from the international market.

Table 5. Level of satisfaction of respondents using IFRS for SMEs

\begin{tabular}{|c|c|c|c|c|c|c|}
\hline $\begin{array}{c}\text { Satisfaction } \\
\text { level }\end{array}$ & $\begin{array}{c}\text { Yes } \\
\text { (MSS\&CF) }\end{array}$ & $\%$ & $\begin{array}{c}\text { No } \\
\text { (MSS\&CF) }\end{array}$ & $\%$ & $\begin{array}{c}\text { Total } \\
\text { number of } \\
\text { respondents }\end{array}$ & $\begin{array}{c}\text { Total } \\
\%\end{array}$ \\
\hline Satisfied & 13 & $59 \%$ & 9 & $41 \%$ & 22 & $100 \%$ \\
\hline
\end{tabular}

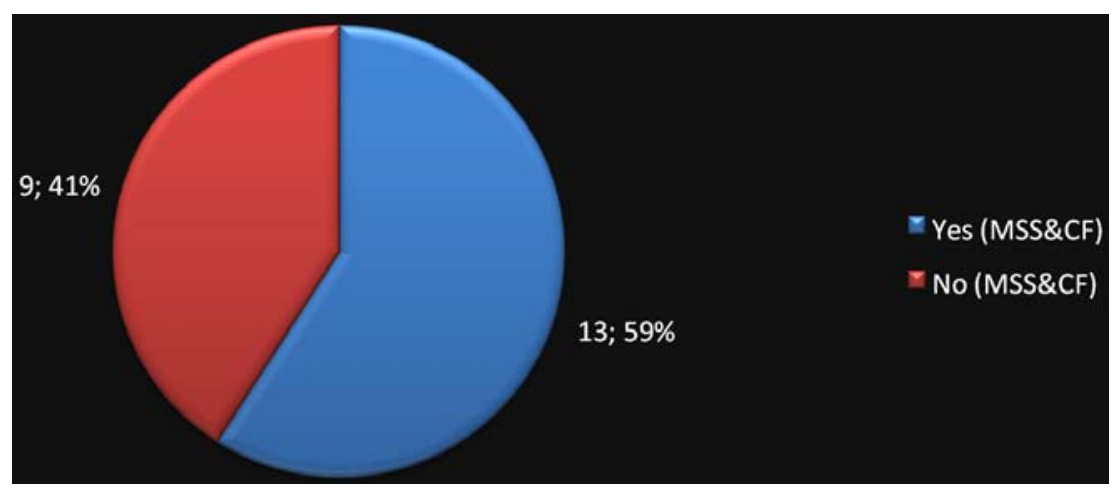

Fig. 6. Level of satisfaction from using IFRS for SMEs

Table 5 shows that, from the 22 respondents who implement IFRS for SMEs, 59\% are satisfied with it, and only $41 \%$ are not satisfied. For those who are satisfied, they cited the quality of the financial statements and creditworthiness of their businesses when applying for bank loans or government tenders, as the main reasons of their satisfaction. Among those who are not satisfied, high cost of implementation was the most cited concern.

Table 6. Reasons for not adopting IFRS for SMEs

\begin{tabular}{|l|c|c|c|c|c|c|}
\hline \multicolumn{1}{|c|}{ Reasons for non-adoption } & Yes (MSS\&CF) & $\%$ & No (MSS\&CF) & $\%$ & Total number of respondents & Total $\%$ \\
\hline Lack of skills & 6 & $75 \%$ & 2 & $25 \%$ & 8 & $100 \%$ \\
\hline Costs more than benefits & 7 & $88 \%$ & 1 & $12 \%$ & 8 & $100 \%$ \\
\hline Unwilling to change & 0 & $0 \%$ & 8 & $100 \%$ & 8 & $100 \%$ \\
\hline Lack of knowledge about IFRS for SMEs & 6 & $75 \%$ & 2 & $25 \%$ & 8 & $100 \%$ \\
\hline
\end{tabular}

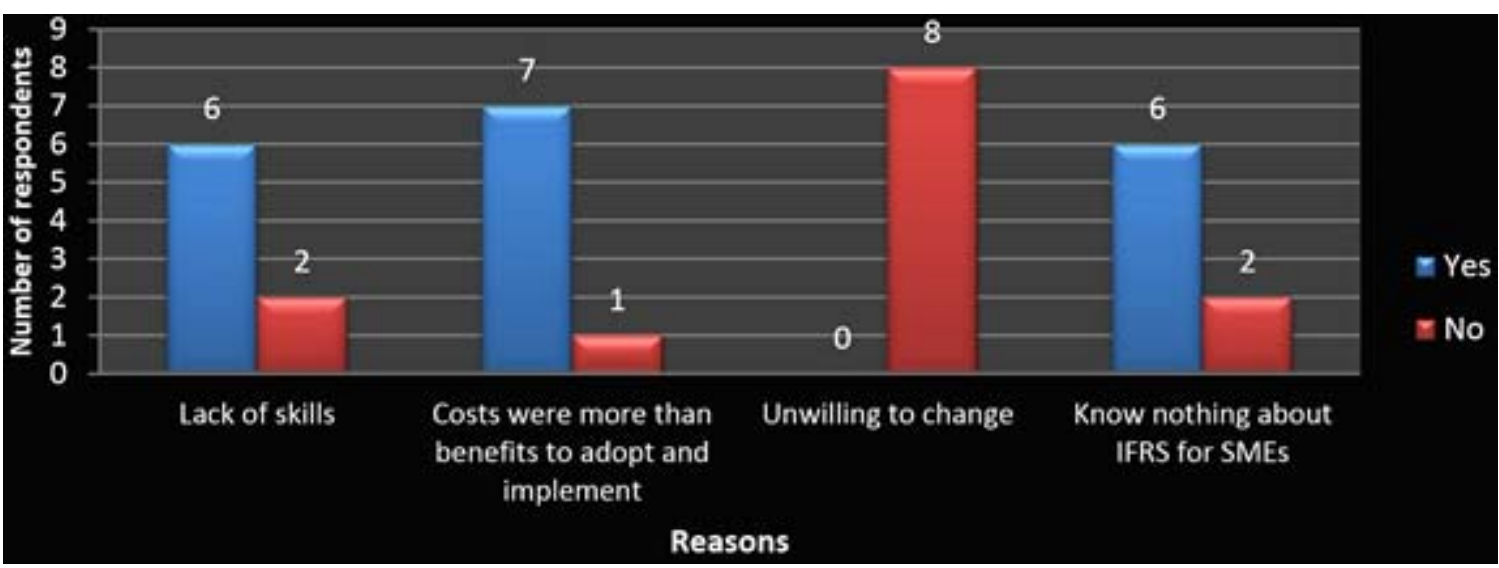

Fig. 7. Reasons for not adopting IFRS for SMEs

Table 6 is aimed at those respondents ( 8 in the sample) who have not adopted the new standards, to identify the reasons for not doing so. Respondents cited cost (88\%), lack of skills (75\%), and lack of awareness $(75 \%)$ as the main reasons for not adopting the IFRS for SMEs. $88 \%$ of the respondents in this group believe that the costs outweigh the benefits. Despite this high percentage, the actual number of the entities that did not adopt the IFRS for SMEs was very small. This simply means that most of small businesses in 
Vhembe are willing to change and implement the new standards, provided the challenges are addressed.

\section{Conclusions}

SMEs in Vhembe District, and by extension, other SMEs in South Africa (67\%), have adopted and implemented IFRS for SMEs, although the challenges for doing so are enormous. In this regard, the question of whether South Africa needs the IFRS for SMEs is no longer an issue, as most SMEs have adopted it despite the existing challenges that they face. Despite this observation, most SMEs who have adopted and are currently implementing the standards, do not see it as serving the main objective of business growth. Empirical evidence suggests that the perception that 'many, if not most' SMEs in Vhembe district have not adopted and implemented the new standards has not been confirmed. For those that did not adopt, they cited low level of awareness, lack of accounting education, training and inability to acquire relevant resources as some of the main obstacles. According to the findings, those SMEs that have adopted the standards cited few indirect benefits experienced when implementing the standard, such as easy access to finance (loans and grants) from the banks and government, doing business with government (tenders) and proper compliance with tax regulations.

It is ironic that, while many developing countries are trying to embrace IFRS for SMEs in totality, the developed countries seem to be lagging behind. Clearly, this situation does create a trust gap in the confidence of using this framework in the preparation of financial statements. Certainly, what is good for the developing countries should equally apply to developed countries, if the ultimate objective is to harmonize financial reporting globally.

\section{Recommendations}

It is clear that the level of IFRS for SMEs adoption and implementation is high in Vhembe District and, by extension, in South Africa, although the rate of those that have not yet adopted (27\%) is equally significant. The study suggests that, among other measures, the following should be done in order to increase the level of adoption and proper implementation:

- review of the IFRS for SMEs to reduce the level of complexity;

- accounting professional bodies should conduct more affordable awareness workshops on the use of IFRS for SMEs;

- more resources should be made available on the internet to provide guidance on how to implement the standards; and

- secondary education must offer curriculum that includes IFRS for SMEs in accounting subjects.

Finally, it is recommended that a follow-up study is conducted in this area, preferably, on a bigger scale to get a wider picture.

\section{References}

1. Australian Accounting Standards Board (AASB). (2010). Retrieved from Differential Financial ReportingReducing Disclosure Requirements: AASB Consultation Paper.

2. Abor, J. \& Quartey, P. (2010). Issues in SME Development in Ghana and South Africa. International Research Journal of Finance and Economics. Available at: http://www.eurojournals.com/irjfe_39_15.pdf.

3. Accounting Practices Board (APB). (2012). Joint Announcement by the APB and the Financial Reporting Standards Council (FRSC) Regarding SA GAAP. Available at: http://www.logista.co.za/downloads/Accounting/Future\%20of\%20SA\%20GAAP.pdf.

4. Alp, A. \& Ustuntag, S. (2009). Financial reporting transformation the experience of Turkey, Critical Perspective on Accounting, 20, pp. 680-699.

5. Anacoreta, L. \& Silva, P. (2005). International Accounting Standards for SME's: an exploratory study. Available at: http://www.porto.ucp.pt/feg/links/papers/IASB_on_SME_Luisa_Anacoreta_e_Duarte_Silva.pdf.

6. Arkava, M. (1983). Beginning social work research. Boston: Allyn \& Baon.

7. Armstrong, C.S., Barth, M.E., Jagolinzer, A.D. \& Riedl, E.J. (2008). Market Reaction to the Adoption of IFRS in Europe. Harvard Business School Working Papers. Available at: http://www.hbs.edu/research/pdf/09-032.pdf. Accessed on 24-03-2010.

8. Balsari, C. \& Varan, S. (2014). IFRS Implementation and studies in Turkey, Accounting and Management Information Systems, 13 (2), pp. 373-399.

9. Collis, J.J. \& Skerratt, L. (2001). Size and the value of the audit, Accounting \& Business, 4 (10), p. 41-42.

10. Deaconu, A.N. \& Popa, I. (2009). Analysis of the stakeholders' needs and their inference upon financial reports of SMEs, Journal of International Business and Economics. Available at: http://findarticles.com/p/articles/mi_6775/is_1_9/ai_n36509542/?tag=content;col1.

11. Dowson, C. (2006). A practical guide to research methods. 2nd edition. United Kingdom: How to use books Ltd.

12. Financial Executives Research Foundation. (2006). What Do Users of Private Company Financial Statements Want? Available at: http://www.pcfr.org/downloads/05_07_.Meet_Materials/FERF_Private_Co_User_Survey.pdf.

13. Harvey, D. \& Walton, P. (1996). Differential Reporting - An Analysis (SME Foundation). London: The Foundation for Manufacturing and Industry. 
14. IASC Foundation Education. (n.d.). Training Material for the IFRS for SMEs. London: IASC Foundation Publications Department.

15. IFC. (2009). The SME Banking Knowledge Guide. Available at: http://www.ifc.org/wps/wcm/connect/industry_ext_content/ifc_external_corporate_site/industries/financial+markets/pub lications/smebk+guide.

16. Institute of Chartered Accountants of England and Wales (ICAEW). (2011). Knowledge Guide to International Accounting Standards. Available at: http://www.icaew.com/en/librarygateways/accounting-standards/knowledgeguide-to-international-accounting-standards.

17. International Accounting Standards Board (IASB). (2007a). Exposure draft of a proposed IFRS for Small Medium-sized Entities. Available at: http://www.saica.co.za/documents/IFRS-Statementsof GAAPforSMEs.pdf.

18. International Accounting Standards Board. (2009). International Financial Reporting Standards (IFRS) for Small and Medium-sized Entities (SMEs) by International Accounting Standards Board (IASB). London: IASB.

19. International Federation of Accountants. (2006). Micro-Entity Financial Reporting: Perspectives of Preparers and Users. Available at: http://www.saipa.co.za/documents/Micro-entity\%20Financial\%20ReportingIFAC\%20Information\%20 Paper.pdf.

20. Irvine, H.J. \& Lucas, N. (2006). The rationale and impact of the adoption of international financial reporting standards on developing nations: the case of the United Arab Emirates. In Proceedings 18th Asian-Pacific Conference on International Accounting Issues, pages pp. 1-22, Maui. Available at: http://eprints.qut.edu.au/13041/.

21. Jarvis, R. \& Collis, J. (2003). IFRSs and Differential Reporting. British Accounting Association Annual Conference of the South Eastern Accounting Group, pp. 1-15.

22. Kennedy, P. \& Emmanuel, E. (2013). Implications of ifrs adoption for SMEs in Nigeria, Fountain Journal of Management and Social Sciences, 2 (1), pp. 36-46.

23. Leedy, P. (2010). Practical research planning and design. 9th edition. Pearson education, Inc.

24. Lekhanya, L. (2013). Functions and Reliability of International Financial Reporting Systems of Rural.

25. Lisa Evans and Roberto di Pietra (2004). Comment on the IASB discussion paper: preliminary views on accounting standards for small and medium-sized entities.

26. Mahembe, E. (2011). Literature Review on Small and Medium Enterprises' Access to Credit and Support in South Africa. Available at: http://www.ncr.org.za/pdfs/Literature\%20Review\%20on\%20SME\%20Access\%20 to\%20Credit\%20in.

27. Management, K.N. (n.d.). International Journal of Academic Research in Accounting, Finance and Management Sciences, 3 (3), pp. 125-132.

28. Munter, P.A. \& Mellentine, J. (2009). Issues In-Depth: A Closer Look at IFRS for SMEs, KPMG Department of Professional Practice, 9 (2), pp. 1-17.

29. Riva, E.S. (2015). Adoption of the International Accounting Standard by Small and Medium-Sized Entities and its Effects on Credit Granting, Revista Contabilidade \& Financa, 26 (69). Available at: https://www.scielo.br/scielo.php?pid=S1519-70772015000300304\&script=sci_arttext\&tlng.

30. Samujh, H.D. (2015). Implementing ifrs for SMEs; challenges for developing economies, International Journal of Management and Sustainability, 4 (3), pp. 39-59.

31. Sian, S. \& Roberts, C. (2009). UK small owner-managed businesses: accounting and financial reporting needs, Journal of Small Business and Enterprise Development, 16 (2), pp. 289-305.

32. Sipahi, B.P. (2007). The Adoption of IFRSs in Turkey: The Auditors' View, The Balkan Countries' 1st International Conference on Accounting and Auditing, 8-9 March 2007, Edirne, Turkey.

33. South Africa: National Planning Commission. (2011). National Development Plan: Vision for 2030.

34. Storey, D.J. (1994). Understanding the Small Business Sector. London: Routledge.

35. Street, D. \& Jr. Needles, B. (2009). Don't Get Caught Short, Journal of Accountancy, 207 (5), pp. 56-57.

36. Survey - Forum on Tax Administration. (2013). SME Compliance Subgroup.

37. United Nations Conference on Trade and Development (UNCTAD). (2007a). Review of Practical Implementation. Available at: https://www.google.co.za/search?q=United+Nations+Conference+on+Trade+and+Develop ment+UNCTAD $+2007 \mathrm{a} \& \mathrm{hl}=\mathrm{enZA} \& \mathrm{biw}=\& \mathrm{bih}=\& \mathrm{gbv}=2 \& \mathrm{oq}=$ United+Nations+Conference+on+Trade+and+Develop ment+UNCTAD+2007a\&gs_l=heirloomserp.12.287324.298322.0.300022.7.6.0.1.0.0.

38. Wong, P. (2004). Challenges successes in implementing international. Standards achieving convergence to IFRSs and IASs. International Federation of Accountants. 